\title{
Foreshocks, Aftershocks and Earthquake Swarms (VI)
}

\author{
-Aftershock Areas and Intensity Distributions due to the Main Shocks-
}

by

\author{
Norio Yamakawa \\ Meteorological Research Institute, Tokyo \\ and Meteorological College, Kashiwa, Chiba Pref.
}

(Received June 30, 1969)

\begin{abstract}
First, it is emphasized that epicenters of large earthquakes are not the centers of source regions, but only starting points of large fractures called "earthquakes," so that it is only natural that the relations between locations of epicenters of large earthquakes and the intensity distribution due to these earthquakes are very peculiar in some cases.
\end{abstract}

Secondly, it is pointed out that the strong correlations can be seen between intensity distributions and aftershock areas as in the case of the Tonankai earthquake on 7 December 1944, because the latters can be considered as the fracturing areas due to the earthquakes concerned.

Thirdly, in more detailed discussion, it is pointed out that aftershock area which show the strong correlations with intensity distributions are not the whole aftershock areas but the area of concentrated aftershock energy where only direct aftershocks in the present author's definition take places.

Lastly, some related geophysical and seismological features are briefly discussed.

\section{Introduction}

The intensity scale of the earthquakes is defined as the degree of its effect of earthquakes on the human body, building structures, earth surface, etc., so that it is qualitative in nature rather than quantitative scale as magnitude scale is. However, for the Japan Meteorological Agency (J.M.A.) one of whose principal duties is prevention of disasters for the service of the general public, the intensity of the earthquake can never be treated as trivial, even if it is a qualitative scale and a not so rigorously quantitative one. Especially in cases of larger earthquakes, seismic intensity is also important from the geophysical viewpoint. Normal and abnormal distributions of seismic intensity give clues to the structures of the crust and upper mantle. (See 
UTSU, 1966) This paper deals with the distribution of earthquake intensity in rela-. tion to the shape of aftershock area.

It has been reported that even within a very small area, intensity changes com-. plicatedly from place to place according to the ground or geological structure. (UTSU, 1968; SUzUKI, 1968) In this paper, however, such details in the distribution of intensity are neglected, and general features of intensity distribution published in the Geophysical Review, Seismological Bulletin and the Preliminary Seismological Report (Jishin. Sokuho) are discussed.

Abnormal distributions of seismic intensity have been well known in Japan. Recently UTSU (1966) reviewed many studies on abnormal distribution of seismic intensity. In the case of deep earthquakes, abnormal intensity distributions are usually

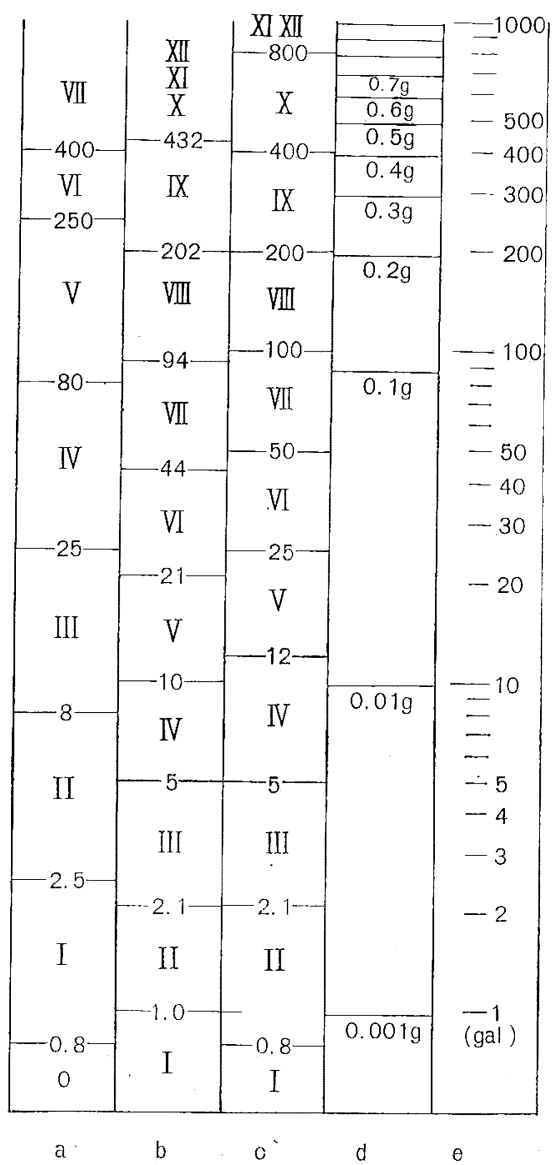

Fig. 1. Comparison of various intensity scales with reference to degrees of accelerations.
(a) J.M.A. scale
(b) Modified Mercalli's scale
(c) M.S.K. scale
(d) Degree of accelerations expressed by ratio to $\mathrm{g}$.
(e) Degree of accelerations in the unit of gal. 
observed, and in the case of shallow earthquakes which occur on the Pacific ocean side of northern Kwanto, Tohoku and Hokkaido, abnormal distributions are frequently observed. UTSU (1966) investigated this abnormal distribution of seismic intensity systematically and reasoned that it is probably due to the fact that in the upper mantle around the Japanese islands there are zones where absorption of seismic waves is small, and stated that this generally agrees with the conclusion previously obtained by Katsumata (1960). On the whole, the conclusion drawn by UtsU seems to be quite adequate and reasonable. In this paper, however, the distribution of seismic intensity of large shallow earthquakes is discussed from a different point of view with special reference to the relation between intensity distribution and aftershock area.

The intensity scale used in this paper is the J.M.A. scale which is adopted by the Japan Meteorological Agency and classifies seismic intensities into 8 grades from 0 to VII. The correspondence of this scale to the modified Mercalli scale and M.S.K. scale is shown in Fig. 1 together with the rough correspondence to the acceleration of ground motion.

\section{Intensity distribution and aftershock area}

Fig. 2 shows the epicenter $\left(33.7^{\circ} \mathrm{N} 136.2^{\circ} \mathrm{E}\right)$ of the Tonakai earthquake on 7 December 1944 and intensity distribution of this earthquake published in the Geophysical Review of 1944. The focal depth of this earthquake was estimated shallower than $30 \mathrm{~km}$. It is worthwhile to notice that, to the west of the epicenter the intensity is rather weak (below grade IV), while, to the east of it, the intensity is strong as naturally expected from the magnitude of the earthquake. Intensity of grade VI is observed here and there, and intensity of grade $\mathrm{V}$ is observed in a wider area. (Incidentally the present author experienced intensity VI at the Ise city $\left(34.5^{\circ} \mathrm{N}, 136.7^{\circ} \mathrm{E}\right)$.)

As discussed in previous papers (YAMAKAWA, 1965, 1967a), the seismological observation system of the J.M.A. was not so dependable as it is at the present day because of the damage due to the Second Wold War, but as far as the hypocenters of the main shock and large aftershocks are concerned, the accuracy of locations is not so unsatisfactory, because redetermination of hypocenters using as many data as possible was done after the war by the staff of the J.M.A. seismological section. As a result the location of epicenter of the main shock may be fairly accurate. Abnormal

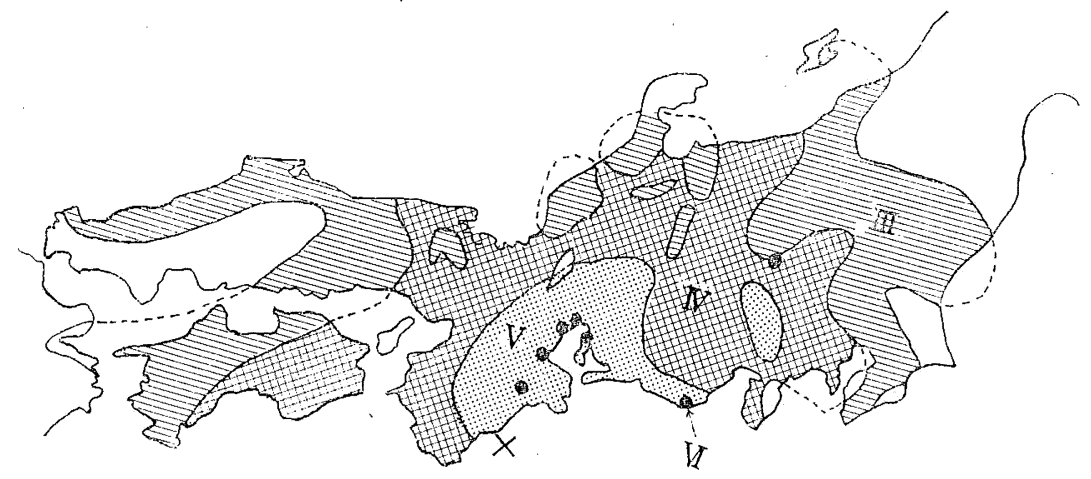

Fig. 2. Intensity distribution and the location of epicenter of the Tonankai earthquake on 7 December 1944. 


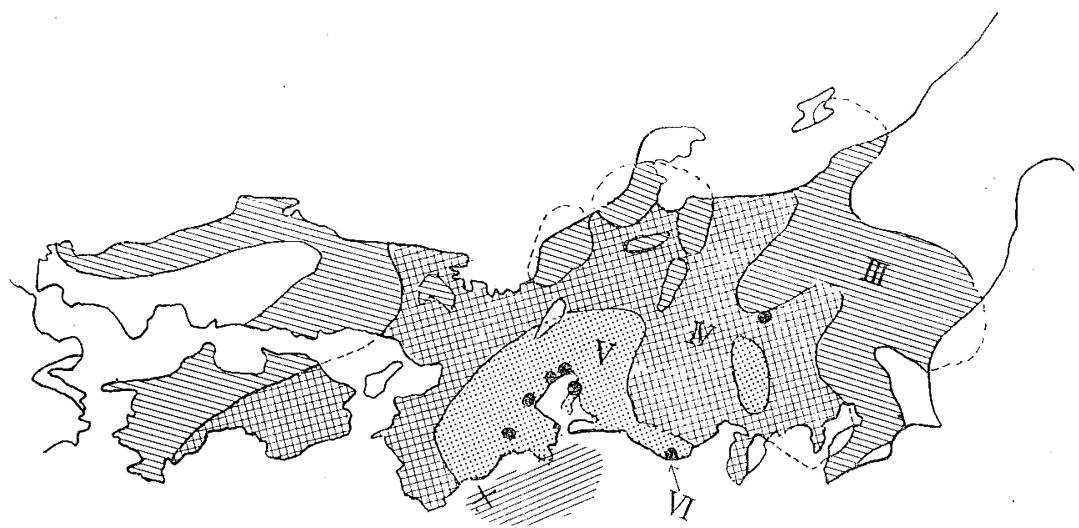

Fig. 3. Intensity distribution, aftershock area and the location of epicenter of the Tonankai earthquake.

distribution of intensity is not usually reported in the case of shallow earthquake in and near the southwestern part of the Japanese islands. What is the reason for this peculiar distribution of intensity in relation to the epicenter of the earthquake? This question can easily be answered if we consider the fact that the epicenter of a large earthquake is only a starting point of large fracture called "earthquake". iStrong intensity can be observed even at places distant from the epicenter, if these places are right above or very near the zone of farcturing due to the earthquake. On the other hand, rather weak intensity may be observed at places not so distant from the epicenter if these places are not near the main fracturing zone. An aftershock area has been considered as the fracturing zone due to the main shock. (See for instance TsuboI, 1956; Utsu, 1961; MogI, 1968; OTsukA, 1964; YAMAKAWA, 1967) Fig. 3 shows the aftershock area (UTSU and SEKI, 1954) of this main shock in addition to the intensity distribution shown in Fig. 2. The epicenter is near the edge of long radius of the ellipse shape of the aftershock area, which extends to northwest from the epicenter. If, as just mentioned, this aftershock area is the fracturing zone due to the main shock, the correspondence between this area and the intensity distribution can be considered fairly satisfactory.

\section{Direct and indirect aftershock areas and intensity distribution}

As often discussed by the present author (YAMAKAWA, 1965, 1966, 1967a, 1968b) the definition of aftershocks is a rather disputable matter. The aftershock area shown in Fig. 3 is the one proposed by UTSU and SErr (1955). 'The aftershock area of this main shock proposed by MoGI (1968) is much larger than the area shown in Fig. 3. The present author explained this kind of difference by introducing the idea of "direct" and "indirect" aftershocks in the above mentioned papers. The aftershock area proposed by UTSU and SEKI is the direct aftershock area, while MoGr took into account not only direct but also indirect aftershocks. (Aftershocks in the Period A and B in Mogr's definition roughly correspond to aftershocks defined by UTSU and SEKI.) It is more natural and reasonable to consider that the fracturing region due to the main shock corresponds to the direct aftershock area than that the region corresponds to the whole aftershock area which includes not only direct but also indirect aftershocks. From this reasoning, the good correspondence between the intensity distribution and aftershock area shown in Fig. 3 can be easily understood. 


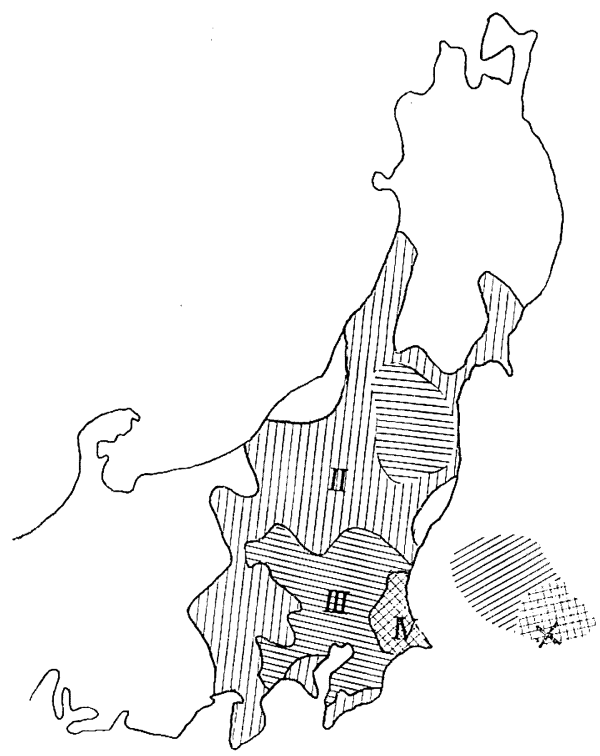

Fig. 4. Intensity distribution, aftershock area and the location of epicenter of the earthquake off Ibaragi Pref. on 16 Jan. 1961.

The earthquake off Ibaragi Pref. on 16 January 1961 is a typical example which shows that not the whole aftershock area but the direct aftershock area has a strong correlation with the intensity distribution due to the main shocks. In Paper II and other papers (YAMAKAWA, 1965, 1967a, 1968b), the present author pointed out that the aftershock area of this earthquake is much larger than that expected from the formula proposed by UTSU and SEKI (1955) and reasoned that the largeness of this aftershock area is due to the fact that not only direct but also indirect aftershocks were induced immediately after the occurrence of the main shock because of the very high seismicity of this region.

Fig. 3 of Paper II shows the distribution of epicenters of the main shock and aftershocks with relative energy estimates of large shocks. The singly hatched area in Fig. 4 shows the whole aftershock area deduced from Fig. 3 of Paper II. Fig. 4 also shows the intensity distribution due to the main shock whose epicenter location is expressed by an $\mathrm{X}$ mark. It is remarkably clear that a very low intensity (grade $\mathrm{I}$ ) area is seen immediately near the aftershock area. This clearly shows that the whole aftershock area which includes not only direct but also indirect aftershocks does not correspond to the fracturing region due to the main shock.

As pointed out by the present author (YAMAKAWA, 1965, 1967a, 1968b), the direct aftershock area in this case may roughly correspond to the area where several large aftershocks took place shortly after the main shock. This area is the narrow south western area near the epicenter of the main shock and is shown by the doubly hatched area in Fig. 4. The relationship between this doubly hatched area and the intensity distribution can be regarded fairly reasonable. Though an anomalous intensity area is seen in the inland Tohoku region, this kind of anomalous distribution of intensity is usually seen in earthquakes in this locality. 


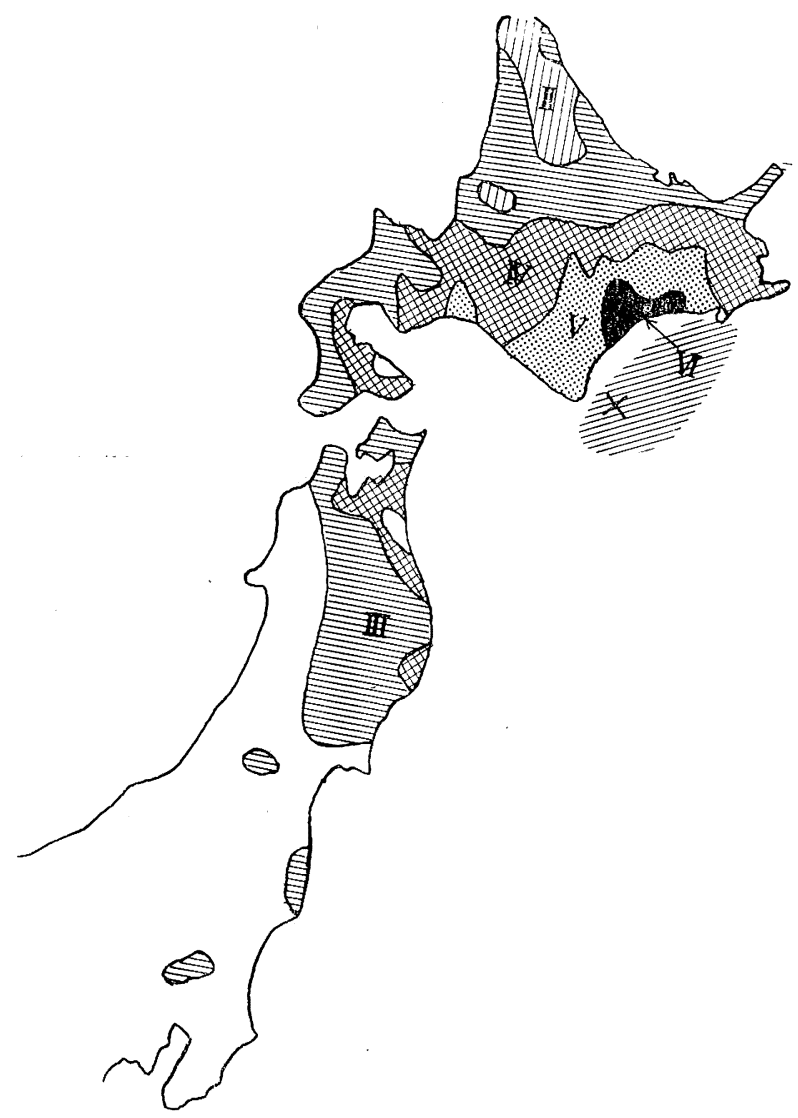

Fig. 5. Intensity distribution, aftershock area and the location of epicenter of the earthquake off Tokachi on 4 March 1952.

Fig. 5 shows the epicenter of the earthquake off Tokachi of 4 March 1952, the aftershock area ${ }^{(1)}$ proposed by UTSU and SEKI (1955), and the intensity distribution due to the main shock. As in the case of the Tonankai earthquake, the relation between the location of the epicenter of the main shock and the seismic intensity distribution due to this shock is very peculiar. The immediate neighborhood of the epicenter does not show the highest intensity, which is recorded at some distance from it, that is, Kushiro city (grade VI). However, the relation between the intensity distribution and the aftershock area is fairly normal. Therefore the aftershock area shown in Fig. 5 can be regarded as corresponding to the fracturing region due to the main shock. So that, in this case too, the strong correlation between the direct aftershock area and the intensity distribution is considered reasonable as in the case of the Tonankai earthquake. On the other hand, the correlation between the indirect aftershock area and intensity distribution is weak as explained in the following.

(1) The energy concentration in the whole aftershock area in this case is as inconspicuous as in the case of the Tonankai earthquake on 7 December 1944. This may imply that the aftershock area shown in Fig. 5 is more or less a direct aftershock area as in Fig. 3. As will be discussed later, this is confirmed by the fact that indirect aftershocks took place in a much wider area in this case. 


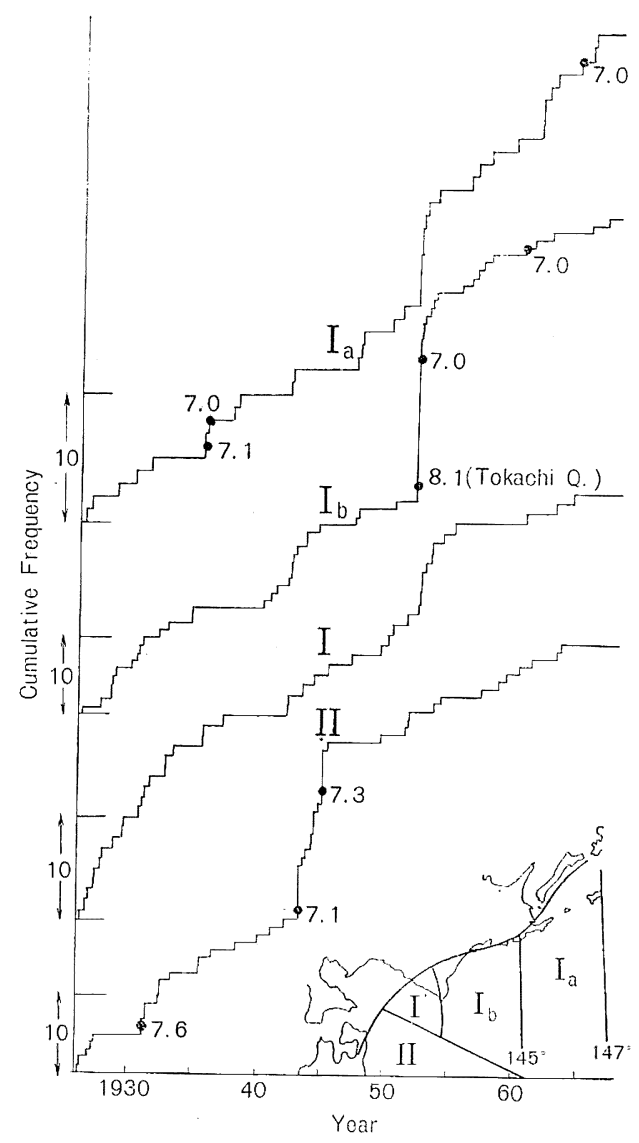

Fig. 6. Cumulative frequencies of earthquakes ( $M \geqq 5.5$ ) against time (UTSU, 1968):

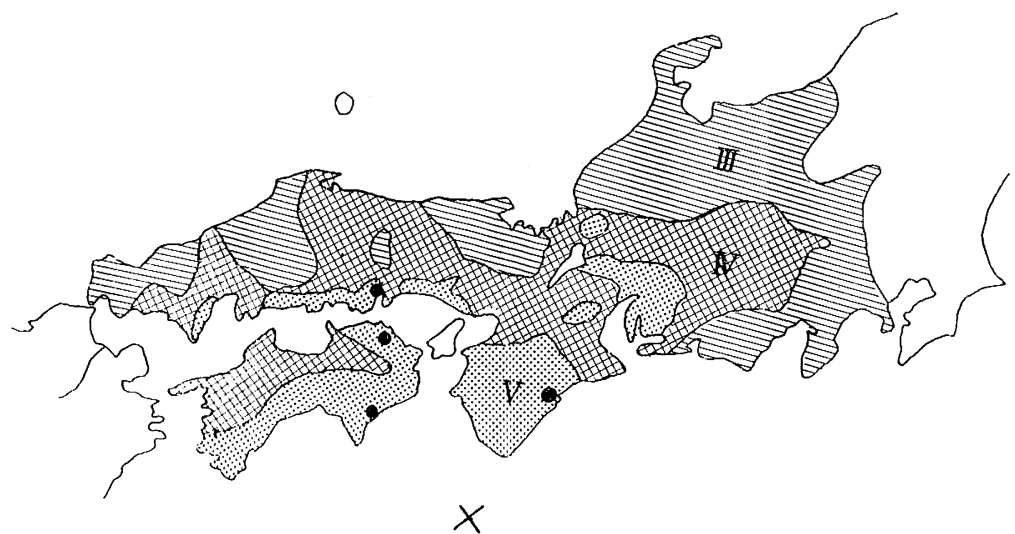

Fig. 7. Intensity distribution and the location of epicenter of the Nankaido earthquake on 21 December 1946.

Fig. 6 shows the cumulative frequencies of earthquakes (whose magnitudes are equal to or greater than 5.5) in areas south of Hokkaido, plotted against time from 
1926 to 1967 (UTSU, 1968). Each cumulative frequency curve represents the seismic activity in each area shown in the map below. It is noteworthy that not only the area Ib which covers the aftershock area proposed by UTSU and SEKI (1955) but also the areas Ia and $I^{\prime}$ show a remarkable increase of semic activity immediately after the occurrence of the main shock. This clearly means that indirect aftershocks by the present author's definition (YAMAKAWA, 1966, 1968b) took place in the areas Ia and I'. But the intensity of the west end of Hokkaido which is in or near the area Ia is relatively low (grade IV).

Fig. 7 shows the intensity distribution due to the Nankaido earthquake on 21 December 1946. Comparison of this figure with Fig. 7 of Paper II (YAMAKAwA, 1967a) which shows the distribution of epicenters of aftershocks with relative energy estimates of large shocks, reveals that the inland area of Shikoku island shows relatively low intensity (grade IV) notwithstanding it is within the aftershock area. However,

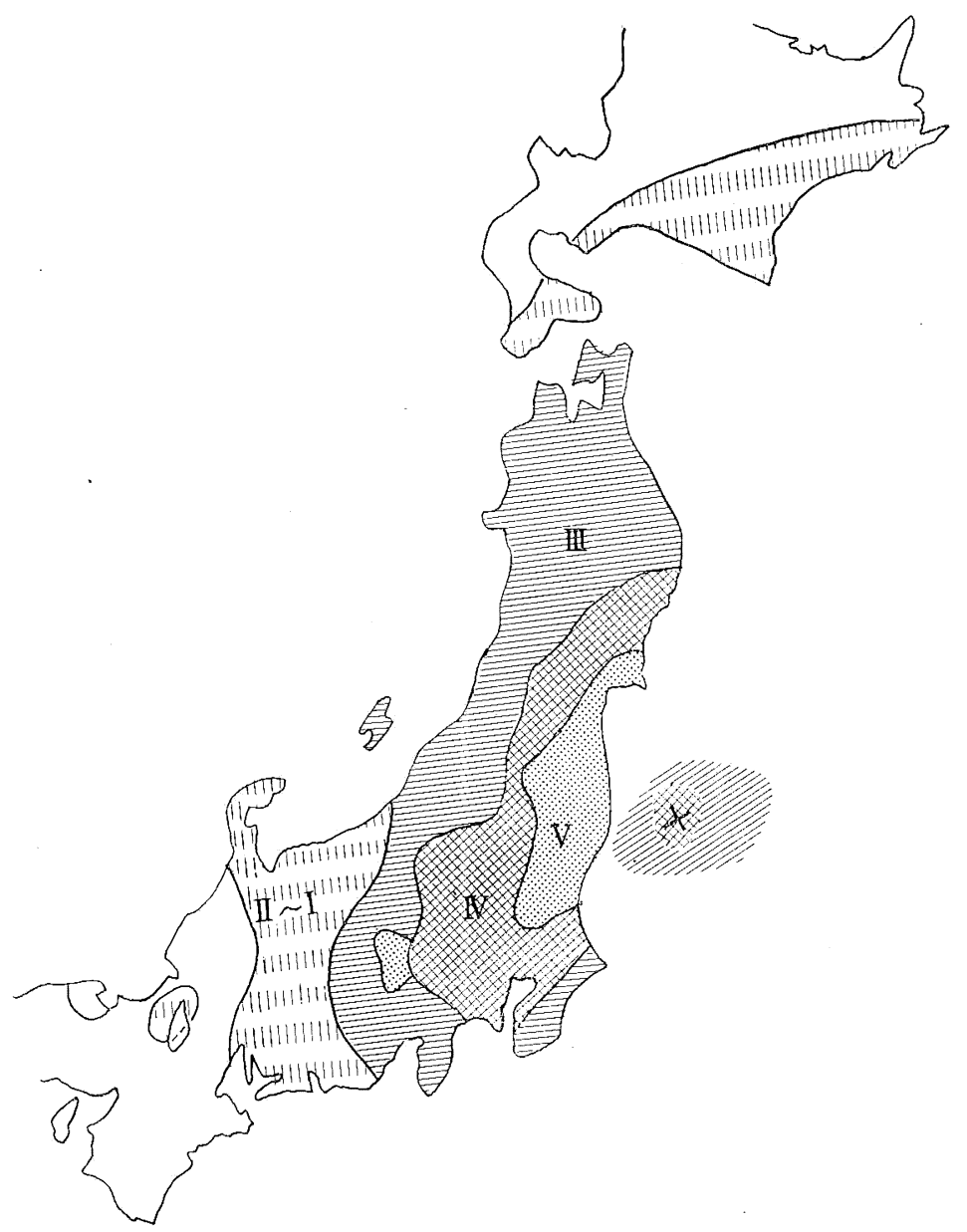

Fig. 8. Intensity distribution, aftershock area and the location of the epicenter of the earthquake off Fukushima Pref. on 5 November 1938. 
if we take not the whole aftershock area shown in Fig. 7 of Paper II but only the area of concentrated aftershock energy pointed out by the present author (YAMAKAWA, 1965, $1967 \mathrm{a}, 1968 \mathrm{~b}$ ), the correlation to the the intensity distribution becomes fairly reasonable except for several anomalous intensity areas which may be explained by the reason proposed by UTSU (1966). As pointed out by the present author (YAMAKAWA, 1965, $1967 \mathrm{a}, 1968 \mathrm{~b}$ ) the area of concentrated aftershock energy coincides with the area of crustal upheaval caused by the main shock and it is fairly reasonable to consider that this corresponds to the fracturing area due to the main shock.

\section{Seismic intensity distribution and other geophysical and seismological features}

Fig. 8 shows the epicenter location of the earthquake off Fukushima Pref. on 5 November 1938, its aftershock area, and the intensity distribution due to this earthquake. The area of concentrated aftershock energy is doubly hatched in the singly hatched whole aftershock area. Though the north-south elongation of isoseismals should be regarded as the manifestation of the geophysical features along the Japanese island arc as pointed out by UTsU (1966), it may also correspond to the elongated

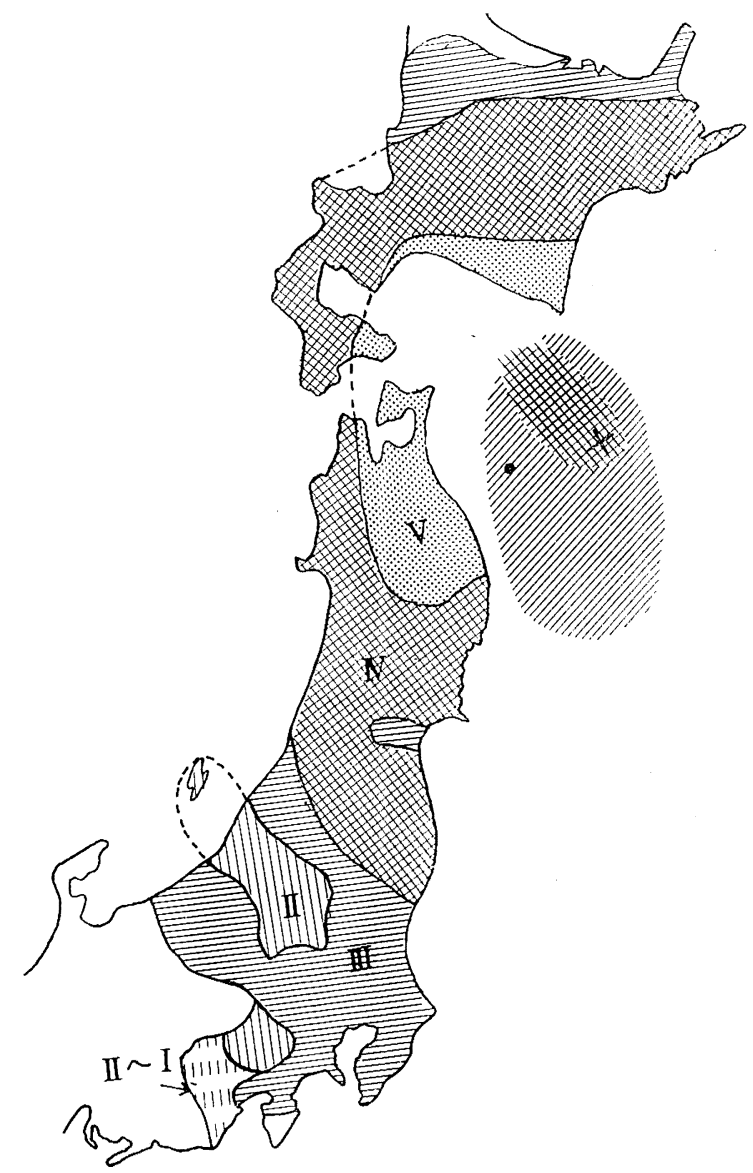

Fig. 9. Intensity distribution, aftershock area and the location of the epicenter of the earthquake off Tokachi on 16 May 1968. 
shape of the area of concentrated aftershock energy. However, the mutual relation between epicenter location of the main shock and the intensity distribution does not show so marked a peculiarity as that in the cases of the Tonankai earthquake on 7 December 1944 and the earthquake off Tokachi on 4 March 1952. The reason for this fact may be that, in the case of the earthquake off Fukushima Pref., the epicenter of the main shock is situated on the edge near the minor axis of the ellipse-like shape of the area of concentrated aftershock energy corresponding to the fracturing area due to the main shock. On the other hand, the epicenters of the Tonankai earthquake and the earthquake of Tokachi of 1952 are situated on the edge near the major axis of the ellipselike shape of fracturing areas. MATUZAWA and HASEGAWA (1954) theoretically pointed out that epicenters of large earthquakes are apt to be situated on the edge near the minor axis of the elliptic source region. Though there are many cases which do not follow this pattern, the earthquake off Fukushima Pref. may be just the case which can be explained by their theory. This may also explain why the relation between locations of epicenters of main shocks and intensity distributions due to the main shocks do not show marked pecularities in some cases, notwithstanding epicenters of main shocks are only the starting points of large factures.

Fig. 9 shows the epicenter of the earthquake off Tokachi on 16 May 1968, its aftershock area, and the intensity distribution due to the main shock. The doubly hatched area in the singly hatched whole aftershock area is the area of the most directly related aftershocks which can be regarded as fracturing phenomena most closely related to the main shock or as a continuation of it in a winder sense. (YAMAKAWA, KISHIO and MAEDA, 1969). The correlation of the intensity distribution with the above mentioned most closely related aftershock area is better than that with the location of the epicenter of the main shock. NAGAMUNe (1968) determined the center of the fracture due to the main shock at the point shown in Fig. 9 from an analysis of the predominant phases of seismograms. Though this center of fracture does not correspond to the fracturing area shown in Fig. 9, the idea that the epicenter of a large earthquake is not the center of fracture but only a starting point of fracture is in agreement with the present author's standpoint. The relation between the center of fracture proposed by Nagamune and the fracturing area obtained as the most closely related aftershock area was discussed in the above mentioned paper.

\section{Conclusion and discussion}

We have pointed out that the epicenters of large earthquakes are not centers of fractures called "earthquakes", but only the starting points of large fractures. So that, in cases of great earthquakes whose magnitudes are about 8.0 and whose linear dimension of the fracturing regions are over several hundred or one thouthand kilometers, the correlations of intensity distributions with the epicenter locations of the main shocks are often poor, especially when the epicenters are situated at the ends of the elongated shape of the fracturing areas.

However, if an epicenter is located at the edge near the minor axis of the ellipselike shape of the fracturing region as in the case of the erathquake off Fukushima Pref., the seismic intensity distribution due to the main shock can be roughly explained in relation with the location of the epicenter of the main shock. This is especially so as regards earthquakes far off the sea coast.

It also has been pointed out that the direct aftershock area corresponds to the 
fracturing area due to the main shock. Here "direct aftershocks" are used in a special sense and can be regarded as parts of the fracture of the main shock itself in a wide sense. (See YAMAKAWA, 1965, 1967a, 1967b, 1968a, 1968b). More refined discussion based upon a more detailed classification of direct and indirect aftershocks will be made in the near future.

As naturally expected, the above mentioned direct aftershock areas correspond to the tsunami source areas. (See, for instance, OMote, 1947; IIDA, 1956; HatorI, 1966; MoGi, 1968; YAMAKAWA, 1968b)

As pointed out at the beginning of this paper, the intensity scale is qualitative in nature, so that the discussion in this paper has been mainly qualitative. Further quantitative studies making use of seismometrical data are desirable. Nagamune's discussion mentioned in the preceding section may be one of these studies. The present author also intends to investigate this problems making full use of seismograms of great earthquakes obtained by the routine observation of the Japan Meteorological Agency in future.

Acknowledgement-This author wishes to express his sincere thanks to Drs. TAKuzo Hirono, Takashi Kizawa, Sei Takagi, Shigeji Suyehiro and Mr. Masahiro Kishio for their kind help and advice.

\section{References}

HATCRI, T., 1966: Vertical displacement in a tsunami source area and the topography of sea bottom. Bull, Earthq. Res. Inst., 44, 1449-1464.

IIDA, K., 1956: Earthquakes accompanied by tsunamis occurring under the sea off the islands of Japan. J. Earth Science Nagoya Univ., 4, 1-43.

Katsumata. M., 1960: The effect of seismic zones upon the transimission of seismic waves. Quart. J. Seismol., 25, 89-95.

Matuzawa, T. and H. Hasegawa, 1954: Feldtheorie der Erdbeben. Elliptisches Quellengebiet., B. E. R. I., 32, 231-246.

MoGi. K., 1968: Development of aftershock areas of great earthquake. Bull. Earthq. Res. Inst., 46, 175-203.

Nagamune, T., 1968: On the phases of maximum amplitude in seismograms of the earthquake off Tokachi of 1968. Read at the autumn session of the seismological society of Japan

Омоте, S., 1947: On the central area of seismic sea waves. Bull. Earthq. Res. Inst., 25, 15-19.

Otsuka, M., 1964: Earthquake magnitude and surface fault formation. J. Phys. Earth, 12, $19-24$.

SUzUKI, S., 1969: Relation between the seismic intensities due to the Tokachi-oki earthquake of 1968 and the underground characteristics in and near Sapporo city. Geophys. Bull. Hokkaido Univ., 21, 107-115.

Tsubor, C., 1956: Earthquake energy, earthquake volume, aftershock area, and strength of the earth's crust, J. Phys. Earth, 4, 63-66.

UTsu, T., 1961: A statistical study on the occurrence of aftershocks. Geophys. Mag., 30, 521-605.

, 1966: Regional differences in absorption of seismic waves in the upper mantle as inferred from abnormal distributions of seismic intensities. J. Fac. Sci. Hokkaido Univ., Ser. VII, 2, 356-374. 1968: Seismic Activity in Hokkaido and its Vicinity (in Japanese). Geophys. Bull. Hokkaido Univ., 20, 51-75.

UTSU, T. and A. SEKI, 1955: A relation between the area of aftershock region and the energy of main shock. Zisin II., 7, 233-240. 
YAMAKAWA, N., 1965: Some investigations of aftershocks. (Part 1) Local concentration of aftershock energy and crustal deformation accompanying the main shock (in Japanese), Zisin, II, 18, 25-40.

, 1966: Foreshocks, aftershocks and earthquake swarms (I), A definition of foreshocks, aftershocks and earthquake swarms and its application to seismicity. Pap. Met. Geophys., 17, 157-189.

, 1967a: Foreshocks, aftershocks and earthquake swarms (II), Areal characteristics of abnormal seismic activities., Pap. Met. Geophys., 18, 15-26.

, 1967b: Foreshocks, aftershocks and earthquake swarms (III), Detailed areal characteristics of aftershock activities. Pap. Met. Geophys., 18, 77-88.

, 1968a: Foreshocks, aftershocks and earthquake swarms with special reference to normal seismic activity in and near the Japanese islands. "The crust and upper mantle of the Pacific area" (Geophysical Monograph No. 12), Amer. Geophys. Union, Washington D. C., 51-59.

, 1968b: Space and time distributions of aftershocks. J. Phys. Earth., 16, Special Issue, $63 \sim 80$.

Yamakawa, N., M. Kishio and I. MAEDA, 1969: Aftershocks of the earthquake off Tokachi of 1968. Read at the spring session of the seismological society of Japan.

\section{前震，余震および群発地震（VI）}

一一余震域と本震による震度分布一

山川, 宜男

最初に, 大地震の震央は, 決して震源域の中心にあたるわけではなく, 単に“地震”と呼ばれる大破壊の出 発点にすぎないこと, それ故時々見られる大地震の震央と, それによる震度分布の対応の悪さは, ある意味 で当然であることを強調した。

第二に，たとえば東南饰地震の場合に和ける様に本震による震度分布と余震域のかなりよい対応は, 後者 が本震による破壊域に対応すると考えられることから理解されることを指摘した。

第三に, もら少し立ら入った議諭として, 本震による震度分布とよい対応を示す余震域は, 所謂全余震域 ではなく，余震域の中で，エネルギー集中を示す狭い地域，すなわち著者の定義による值接的な余震だけが 扣こる地域であることを指摘した。

最後に, 関連した地球物理学的, 地震学的諧特徽を簡単に論じた。 